Revista Monografias Ambientais

Santa Maria, v. 14, n. 3, Set-Dez. 2015, p. 64-75

Revista do Centro de Ciências Naturais e Exatas - UFSM

ISSN : 22361308

\title{
Ações práticas e de educação ambiental visando preservar nascentes, Dona Francisca, RS
}

\author{
Practice actions and environmental education to preserve sources, Dona Francisca, $R S$ \\ Dorli Elso Barichello스, Damaris Kirsch Pinheiro², Daniele Guarienti Rorato ${ }^{2}$ \\ Empresa de Assistência Técnica e Extensão Rural (EMATER/RS-ASCAR), Escritório Municipal de Dona \\ Francisca, Universidade Federal de Santa Maria
}

\begin{abstract}
Resumo
O trabalho teve como objetivo apresentar as atividades desenvolvidas no Programa Proteção de Nascentes, realizado no município de Dona Francisca, RS. A falta de abastecimento de água em grande parte das propriedades rurais e o descaso com as nascentes levaram o governo municipal juntamente com a EMATER/RS-ASCAR do município, a partir de 1990, a realizar atividades de limpeza visando proteger esses locais da entrada de sedimentos contaminantes ou acesso de animais. Adicionalmente, teve-se o cuidado também com o entorno das nascentes, deixando a área protegida com isolamento, uso de práticas como o terraceamento para desvio das águas superficiais, plantio de árvores nativas no entorno quando necessário, entre outras recomendações. Das 12 nascentes analisadas, 50\% foram consideradas preservadas e o restante foi considerado como necessitando intervenção. Além disso, destaca-se a realização concomitante de atividades de educação ambiental junto às famílias e crianças dessas comunidades beneficiadas. A partir da realização conjunta dessas atividades foi possível perceber uma mudança comportamental nos indivíduos, na maneira de pensar e agir, refletindo em ações mais conscientes $e$ responsáveis para com o meio ambiente.
\end{abstract}

Palavras-chave: Área de Preservação Permanente. Pequenas propriedades rurais. Recurso hídrico.

\begin{abstract}
The study aimed to present the activities developed in the Protection Spring Water Program, conducted in the municipality of Dona Francisca, RS. The lack of water supply in most of the farms and the neglect of the sources led the city government together with the EMATER/RS-ASCAR the city, from 1990 to perform cleanup activities to protect these places of entry sediment contaminants or animal access. In addition, care is had also to the vicinity of the springs, leaving the area protected with insulation, use of practices such as terracing for diversion of surface water, planting native trees in the vicinity when necessary, among other recommendations. Of the 12 analyzed springs, $50 \%$ were considered preserved and the rest was as needing intervention. Furthermore, there is the concomitant realization of environmental education activities with the families and children of these beneficiary communities. From the combination of these activities was possible to see a behavioral change in individuals, in the way of thinking and acting, reflecting more aware and responsible actions towards the environment.
\end{abstract}

Keywords: Permanent Preservation Area. Small farms. Water resource. 


\section{Introdução}

A água é fundamental para a manutenção dos ecossistemas e contribui para o processo de absorção dos nutrientes no solo pelos vegetais além de atenuar a temperatura do ambiente, entre outros benefícios. Contudo, esse recurso natural encontra-se ameaçado pela atuação impactante do homem nas bacias hidrográficas, devido as cargas poluidoras lançadas na natureza e a remoção da cobertura vegetal.

Nesse contexto, o meio rural e uma das suas principais atividades, a agricultura, estão alterando a quantidade e qualidade da água disponível. Conforme Casali (2008), a redução na disponibilidade desse recurso natural tem se tornado um dos grandes limitadores para a produtividade das culturas. Além da escassez desse recurso, a agricultura, quando executada sem controle, gera efeitos indiretos no ecossistema e altera a qualidade da água disponível, causando poluição dos cursos d'água devido à utilização intensiva de defensivos e fertilizantes; bioacumulação, eutrofização dos mananciais e salinização dos solos.

Além disso, a poluição atmosférica, às atividades intensivas de criação de animais, a poluição hídrica pela acumulação de metais pesados e produtos tóxicos provenientes da atividade industrial, desmatamentos, queimadas e impermeabilização dos solos pelas atividades humanas acarretam problemas de escassez e diminuição da qualidade da água útil disponível. Todas essas atividades colocam em risco a manutenção da vida na terra, dentro de um curto espaço de tempo (CONBOY; GOSS, 2000; GONÇALVES, 2003).

Assim, dada a importância do manancial para o suprimento de água com quantidade e qualidade e o papel fundamental de filtro natural da vegetação ciliar (BAHIA, 2007), as florestas ou outro tipo de vegetação, localizada no entorno de nascentes, olhos d'água, ao longo dos rios, e demais situações estabelecidas na Legislação Federal, Lei 12.651 de 2012, são consideradas como Áreas de Preservação Permanente (APP) (BRASIL, 2012).

Considerando a necessidade de preservação desses locais e a problemática da qualidade da água, no município de Dona Francisca, RS, o governo municipal juntamente com a Empresa de Assistência Técnica e Extensão Rural (EMATER/RS-ASCAR), implementaram no ano de 1990 um Programa, denominado Proteção de Nascentes (Fonte-Drenada), visando proteger esses locais da entrada de sedimentos contaminantes, acesso de animais e manutenção da vegetação do entorno.

Esse programa foi voltado às famílias rurais do interior desse município, que não recebiam água pela rede de abastecimento e cujas nascentes apresentaram problemas com a qualidade da água. Aliado a isso, são realizadas atividades de educação ambiental, com adultos e crianças, de escolas do município, visando demonstrar a importância e a necessidade de preservação desses locais, para a manutenção dos recursos hídricos, fauna e flora associada.

Nesse sentido, esse trabalho teve por objetivo apresentar as atividades desenvolvidas no Programa Proteção de Nascentes (Fonte-Drenada), realizado no município de Dona Francisca, RS, região Central do Estado do Rio Grande do Sul.

\section{Material e Métodos}

\subsection{O Programa Proteção de Nascentes (Fonte-Drenada)}

O município de Dona Francisca pertence à Quarta Colônia de Imigração Italiana e está localizado na região central do estado do Rio Grande do Sul. Possui unidade territorial de $114 \mathrm{~km}^{2}$ e altitude de 
64 m do nível do mar, apresentando no ano de 2010, 3.401 habitantes, dos quais 2.146 residem na região urbana e 1.255 no meio rural (IBGE, 2010).

A grande maioria das residências do município localiza-se nas áreas de encostas e morros. É também nessas áreas que se encontram as nascentes, responsáveis pelo abastecimento de residências e propriedades rurais. Algumas, consideradas de pequeno porte, merecem maior atenção, devido, principalmente, à dificuldade de suprir o abastecimento familiar.

Contudo, a falta de abastecimento de água em grande parte das propriedades rurais e o descaso com as nascentes, levaram o governo municipal de Dona Francisca juntamente com a EMATER/RSASCAR (Empresa de Assistência Técnica e Extensão Rural), a realizar atividades visando proteger esses locais da entrada de sedimentos contaminantes ou acesso de animais.

Nesse sentido, teve início no ano de 1990, o Programa denominado Proteção de Nascentes (FonteDrenada). Famílias rurais do interior desse município, que faziam uso da água proveniente de nascentes para consumo foram convidadas a aderir ao Programa, em especial aquelas cujas análises bacteriológicas de amostras de água, realizadas pelo Departamento de Saúde da Comunidade da Universidade Federal de Santa Maria indicavam problemas bacteriológicos ou presença de coliformes. Inicialmente, o grupo de pessoas a qual a nascente beneficiava era convidado a participar de reuniões tratativas e de esclarecimentos. Essa fase do Programa ocorreu do ano de 1990 a 1992. Nessas ocasiões, os técnicos da EMATER/RS- ASCAR realizavam palestras enfocando a necessidade de preservação dos recursos hídricos e importância da qualidade da água, entre outros temas. Após, a partir de 1993, dando prosseguimento as atividades eram realizados dias de campo, com a presença dos técnicos e o apoio do grupo envolvido visando à proteção das nascentes. As etapas necessárias para a proteção de uma nascente, orientações fornecidas pelos técnicos bem como algumas práticas recomendadas para o entorno da nascente podem ser observadas em Barichello (2011). Todas essas atividades foram realizadas pelos técnicos da EMATER/RS- ASCAR juntamente com os beneficiários do Programa, do ano de 1990 até final de 2014.

Do ano de 1990 até 2014, um total de 79 nascentes foram protegidas no município de Dona Francisca. Para efeito dessa análise, dessas 79 nascentes foram selecionadas 12 para avaliação, classificadas como de atendimento grupal, ou seja, beneficiavam um número mínimo de quatro famílias. As nascentes analisadas no presente estudo foram protegidas entre os anos de 1993 a 1996, e estão localizadas em diferentes localidades do interior desse município, conforme coordenadas apresentadas na Tabela 1.

Tabela 1 - Localização das nascentes analisadas integrantes do Programa Proteção de Nascentes (Fonte-Drenada), Dona Francisca, RS.

\begin{tabular}{ccc}
\hline Nascente & Localidade & Coordenadas geográficas \\
\hline Nascente 01 & Cerro Dambrós & $29^{\circ} 34^{\prime} 52.37^{\prime \prime}$ S e $53^{\circ} 20^{\prime} 31.61^{\prime \prime} \mathrm{W}$ \\
Nascente 02 & Formoso & $29^{\circ} 34^{\prime} 34.05^{\prime \prime}$ S e $53^{\circ} 20^{\prime} 58.02^{\prime \prime} \mathrm{W}$ \\
Nascente 03 & Cerro Dambrós & $29^{\circ} 35^{\prime} 12.95^{\prime \prime}$ S e $53^{\circ} 19^{\prime} 44.40^{\prime \prime} \mathrm{W}$ \\
Nascente 04 & Cerro Dambrós & $29^{\circ} 34^{\prime} 54.57^{\prime \prime}$ S e $53^{\circ} 19^{\prime} 46.09^{\prime \prime} \mathrm{W}$ \\
Nascente 05 & Linha do Moinho & $29^{\circ} 35^{\prime} 25.79^{\prime \prime}$ S e $53^{\circ} 22^{\prime} 30.88^{\prime \prime} \mathrm{W}$ \\
Nascente 06 & Formoso & $29^{\circ} 34^{\prime} 21.77^{\prime \prime}$ S e $53^{\circ} 21^{\prime} 26.18^{\prime \prime} \mathrm{W}$ \\
Nascente 07 & Trombudo & $29^{\circ} 32^{\prime} 18.44^{\prime \prime}$ S e $53^{\circ} 21^{\prime} 16.29^{\prime \prime} \mathrm{W}$ \\
Nascente 08 & Sanga Funda & $29^{\circ} 29^{\prime} 48.99^{\prime \prime}$ S e $53^{\circ} 21^{\prime} 23.45^{\prime \prime} \mathrm{W}$ \\
Nascente 09 & Sanga Funda & $29^{\circ} 29^{\prime} 54.38^{\prime \prime}$ S e $53^{\circ} 19^{\prime} 28.54^{\prime \prime} \mathrm{W}$
\end{tabular}


Nascente 10

Nascente 11

Nascente 12
Linha Grande

Linha Grande

Linha do Soturno $29^{\circ} 35^{\prime} 48.96^{\prime \prime}$ S e $53^{\circ} 19^{\prime} 39.75^{\prime \prime} \mathrm{W}$

$29^{\circ} 35^{\prime} 38.75^{\prime \prime} \mathrm{S}$ e $53^{\circ} 20^{\prime} 06.88^{\prime \prime} \mathrm{W}$

$29^{\circ} 37^{\prime} 10.21^{\prime \prime}$ S e $53^{\circ} 22^{\prime} 11.38^{\prime \prime} \mathrm{W}$

Todas as informações obtidas sobre o Programa Proteção de Nascentes (Fonte-Drenada) foram fornecidas por 2 funcionários, os quais atuam como técnicos da EMATER/RS- ASCAR, no Escritório Municipal de Dona Francisca, RS. Tais informações, as quais serviram como base de dados para a fundamentação desse trabalho foram obtidas via comunicação pessoal com os técnicos, visto que esses acompanharam e executaram todas as atividades envolvidas durante a implementação e execução do Programa (PINZON; BARICHELLO, 2014).

Assim, após seleção e identificação da localização das nascentes, foi realizada uma checagem a campo, por meio de uma única visita a cada nascente, para analisar a situação atual das mesmas, verificando a conformidade com o indicado na ocasião da proteção, informações essas obtidas previamente mediante contato com técnicos participantes do Programa, via comunicação pessoal (PINZON; BARICHELLO, 2014). A realização das checagens ocorreram durante 6 dias $(16,17,23,24$, 30 e 31 de agosto de 2014), sendo visitadas 2 nascentes a cada dia. A realização da vistoria foi feita pelos autores desse trabalho, contudo, previamente a realização da mesma foi solicitado aos proprietários das áreas e/ou responsáveis pelas nascentes, autorização para visita ao local.

Durante a vistoria, aspectos como localização da nascente e análise do entorno foram considerados, em especial, a proximidade com lavouras, áreas de pastagens, acesso de animais, isolamento da área e presença de construções. Esses aspectos são considerados fundamentais para garantir a preservação ambiental desses locais.

Assim, nos casos em que foi verificada a não conformidade com o recomendado na ocasião de proteção da nascente, foi realizada uma conversa junto aos proprietários responsáveis e entregue recomendações para melhoria ambiental do local, as quais encontram-se em Barichello (2014).

\subsection{Atividades de Educação Ambiental}

Como forma de dar continuidade ao trabalho de sensibilização e conscientização realizado pelos técnicos da EMATER/RS-ASCAR, Escritório Municipal de Dona Francisca, RS, mediante a execução do Programa Proteção de Nascentes (Fonte-Drenada), foram realizadas nesse trabalho atividades de educação ambiental com crianças. As atividades de educação ambiental foram realizadas com crianças em idade escolar, alunos do $4^{\circ}$ e $5^{\mathfrak{o}}$ ano da Escola Municipal Tiradentes e da Escola Estadual de Ensino Médio Maria Ilha Baisch, localizadas na comunidade de Trombudo, interior de Dona Francisca e na área urbana do município, respectivamente. Durante o ano de 2014, foram realizadas duas trilhas ecológicas, uma no mês de maio e a outra no mês de outubro, com um total de até 45 alunos por trilha.

Durante a caminhada, realizada especialmente em uma trilha ecológica existente dentro de um remanescente de Mata Atlântica, localizado na comunidade de Trombudo, foram destacados aspectos do ambiente, nas estações pré-programadas com diversos temas. Na primeira estação foi apresentado a história da propriedade, por ser tratar de uma das primeiras residências de colonização italiana na região. Na segunda estação, junto ao córrego e a mata ciliar bem formada e em uma encosta de afloração rochosa do lençol freático Guarani, foram enfatizados aspectos relacionados com a importância das matas ciliares para as encostas, nascentes, arroios e rios e os cuidados necessários com os recursos hídricos.

Na terceira estação, foram abordados aspectos da fauna, pois no local há uma pequena caverna habitada por morcegos e no entorno ninhos de pássaros, presença de plantas hospedeiras e de mutualismo entre os indivíduos, ressaltando-se assim suas funções para um ecossistema equilibrado e 
protegido. A quarta estação encontra-se em local de vegetação baixa, onde podem ser observados diversos estádios de vegetação, entre outros aspectos.

Na quinta estação, já dentro da mata bem formada, foi destacado a importância das matas para o meio ambiente como um todo, ressaltando-se suas funções e benefícios para a fauna, flora, solo e água. Ao final da trilha, na sexta estação, os participantes foram convidados a contemplar uma bela cascata em meio à mata fechada, seguido de momentos de reflexão e avaliação do ocorrido até o momento.

Ressalta-se que no inicio da realização da trilha sempre foram tomadas algumas precauções com relação à segurança da turma, como o acompanhamento de profissional da saúde, bem como professores e pais convidados a participarem da trilha. Neste momento foram repassados orientações necessárias para a realização de uma trilha com segurança e responsabilidade, para evitar possíveis acidentes ou atos indesejáveis, mesmo sendo uma trilha de pequena dificuldade.

\section{Resultados e Discussão}

\subsection{Análise das nascentes}

Cada nascente selecionada foi vistoriada com o intuito de verificar, passado um período de tempo da realização do Programa, a situação atual da mesma. Na ocasião, aspectos como a proximidade com lavouras e áreas de pastagens, acesso de animais, isolamento da área e presença de construções foram considerados. A situação original, a situação atual e a recomendação de cada uma das 12 nascentes avaliadas pode ser observado na Tabela 2.

Com base na análise da situação atual, evidencia-se que as nascentes 02 , 08 e 10 (25\% das nascentes analisadas) requerem intervenções que começam, inicialmente, com o isolamento da área para impedir o acesso do gado ao local (Tabela 2). Essa medida necessita ser adotada tendo em vista que, conforme Gandolfi e Rodrigues (1996), essa é, em muitos casos, a principal iniciativa para que se interrompa a degradação de uma área, quando o agente de degradação é o gado ou o fogo, por exemplo. Nesses casos, segundo esses autores, cercar a área ou construir e manter aceiros ao seu redor são medidas simples e eficientes, quando existe interferência do gado ou fogo, respectivamente.

No caso dessas nascentes (nascentes 02, 08 e 10), delimitar a área a ser preservada mediante a construção de cercas e de bebedouros para que os animais possam ter acesso à água, impedirá que esses acessem as áreas causando danos. Os danos causados pelo acesso de animais já foram descritos na literatura. Schneider; Galvão; Longhi (1978) relataram que o pisoteio do gado causa exposição da superfície do solo, danifica raízes superficiais e prejudica a regeneração natural. Além disso, Miranda e Muniz (2009) avaliando o impacto do gado bovino sobre os ecossistemas do Parque Estadual do Mirador (PEM), localizado no estado do Maranhão, afirmaram que a presença desses animais nas cabeceiras de riachos no PEM, causou impacto nestes ecossistemas, principalmente na composição florística das espécies existentes no local.

Diante dos danos proporcionados as áreas, sugere-se inicialmente o isolamento das nascentes 02 , 08 e 10 (Tabela 2), e após, passado um período de tempo, um segunda avaliação poderá indicar a necessidade ou não da utilização de técnicas de restauração, como o plantio de mudas, semeadura direta, condução da regeneração natural, transplante de plântulas (NAVE, 2005), uso de poleiros artificiais ou naturais (REIS; KAGEYAMA, 2003). O critério para escolha da técnica de restauração a ser utilizada deverá considerar o potencial de resiliência da área, buscando-se com isso a efetiva recuperação do ambiente.

Em muitas situações evidenciadas nesse estudo, impedir o acesso direto de animais, mediante o isolamento da área (nascentes 02, 08 e 10) e reduzir a erosão do solo, adotando o uso de práticas conservacionistas (nascente 09) é uma das formas de possibilitar que a vegetação nativa e a regeneração natural dessas espécies tenham melhores condições para se desenvolver.

Além disso, ao analisar o conjunto das 12 nascentes consideradas nesse estudo, evidencia-se que $50 \%$ dessas encontram-se preservadas, sendo necessário apenas a manutenção das práticas 
conservacionistas do solo, da vegetação e da limpeza da nascente, para garantir o suprimento de água em quantidade e qualidade. Contudo, os outros 50\% das nascentes analisadas encontraram-se comprometidas, necessitando de algum tipo de intervenção que pode ser desde o abandono de uma faixa de área maior no entorno da nascente, a colocação de cercas para impedir o acesso de animais ao local como até mesmo a necessidade de refazer a estrutura de proteção da nascente (Tabela 2).

Cabe ressaltar que embora elevado, o percentual de nascentes que necessitam de alguma intervenção pode ter sido influenciado pelo número de nascentes analisadas nesse estudo em comparação com o número total de nascentes protegidas no município de Dona Francisca. 
Tabela 2 - Detalhamento da situação original e atual das nascentes analisadas, Programa Proteção de Nascentes (Fonte-Drenada), Dona Francisca, RS.

\begin{tabular}{|c|c|c|c|}
\hline Nascente & Situação Original* & Situação Atual & Recomendação \\
\hline 01 & $\begin{array}{l}\text { Estava localizada em área de potreiro com acesso de } \\
\text { animais, entrada de águas superficiais em períodos } \\
\text { de chuvas torrenciais e pouca vegetação no entorno. }\end{array}$ & $\begin{array}{l}\text { Nascente preservada, em pleno } \\
\text { funcionamento e bom estado de } \\
\text { conservação. Não permite o acesso de } \\
\text { animais e humanos e o terraço construído } \\
\text { para proteção da entrada de águas } \\
\text { superficiais ainda está presente. }\end{array}$ & $\begin{array}{l}\text { Dado o pleno funcionamento e o bom } \\
\text { estado de conservação da nascente, } \\
\text { apenas foi solicitado aos responsáveis } \\
\text { que continuassem com as práticas } \\
\text { realizadas. }\end{array}$ \\
\hline 02 & $\begin{array}{l}\text { Parte do local estava protegido apenas com vegetação } \\
\text { rasteira (capoeira), entretanto nas demais áreas } \\
\text { evidenciava-se ausência de vegetação, além da } \\
\text { proximidade da nascente com a lavoura de fumo. }\end{array}$ & Necessidade de intervenção. & $\begin{array}{l}\text { Aumentar o raio de isolamento } \\
\text { impedindo que os animais pisoteiem } \\
\text { ou se alimentem da regeneração } \\
\text { natural. }\end{array}$ \\
\hline 03 & $\begin{array}{l}\text { A nascente estava localizada em meio a uma capoeira } \\
\text { e próxima das residências possibilitando o acesso de } \\
\text { animais. }\end{array}$ & $\begin{array}{l}\text { Nascente preservada, bem estruturada e em } \\
\text { pleno funcionamento, sendo encontrada em } \\
\text { área de mata vigorosa e bem preservada. }\end{array}$ & $\begin{array}{l}\text { Foi orientado aos lindeiros que } \\
\text { mantivessem a nascente conforme a } \\
\text { realidade encontrada. }\end{array}$ \\
\hline 04 & $\begin{array}{l}\text { Encontrava-se em meio à vegetação rasteira, com } \\
\text { algumas árvores esparsas. No entorno e acima da } \\
\text { nascente encontravam-se lavouras de fumo e milho. } \\
\text { Além disso, evidenciou-se a entrada de água de } \\
\text { enxurradas o que causava turbidez e alterava a } \\
\text { palatabilidade da água nessas ocasiões. }\end{array}$ & Necessidade de intervenção. & $\begin{array}{l}\text { Necessidade de manutenção para } \\
\text { melhorar a captação, pois grande } \\
\text { volume de água está sendo perdido. }\end{array}$ \\
\hline 05 & $\begin{array}{l}\text { A nascente estava localizada em meio à mata nativa } \\
\text { de grande porte, sem acesso de animais ou até mesmo } \\
\text { de humanos e com entorno muito bem protegido. }\end{array}$ & $\begin{array}{l}\text { Nascente preservada, com entorno } \\
\text { protegido pela mata nativa de grande porte, } \\
\text { difícil acesso de pessoas e sem acesso de } \\
\text { animais. }\end{array}$ & $\begin{array}{l}\text { Dado o pleno funcionamento e o bom } \\
\text { estado de conservação da nascente, } \\
\text { apenas foi solicitado aos responsáveis } \\
\text { que continuassem com as práticas } \\
\text { realizadas. }\end{array}$ \\
\hline 06 & $\begin{array}{l}\text { A nascente estava em área protegida por cerca, sem o } \\
\text { acesso de animais de grande porte, cujo entorno } \\
\text { apresentava área de capoeira e vegetação baixa e } \\
\text { densa. A mesma encontrava-se coberta, sem uma } \\
\text { maior proteção contra o acesso de pequenos animais. }\end{array}$ & Necessidade de intervenção. & $\begin{array}{l}\text { A proteção de material apresenta } \\
\text { problemas. O entorno passou a ser uma } \\
\text { área de acúmulo de água (pequeno } \\
\text { banhado), podendo comprometer, em } \\
\text { parte, a qualidade da água captada. }\end{array}$ \\
\hline
\end{tabular}


Tabela 2 - Detalhamento da situação original e atual das nascentes analisadas, Programa Proteção de Nascentes (Fonte-Drenada), Dona Francisca, RS.

\begin{tabular}{|c|c|c|c|}
\hline Nascente & Situação Original* $^{*}$ & Situação Atual & Recomendação \\
\hline 07 & $\begin{array}{l}\text { Localizada em área de difícil acesso, em meio } \\
\text { à mata densa, local protegido e sem focos de } \\
\text { destruição no entorno. }\end{array}$ & $\begin{array}{l}\text { Nascente preservada, } \\
\text { destacando a presença de mata } \\
\text { densa no entorno. }\end{array}$ & $\begin{array}{l}\text { Dado o ótimo estado de conservação, apenas orientou-se } \\
\text { quanto à manutenção das práticas realizadas. }\end{array}$ \\
\hline 08 & $\begin{array}{l}\text { Entorno com pequena vegetação arbórea e } \\
\text { acesso de animais. O entorno era cultivado } \\
\text { com fumo, feijão e milho, o que combinado } \\
\text { com a declividade do terreno e a direção da } \\
\text { água da chuva, provocava o assoreando da } \\
\text { nascente. }\end{array}$ & Necessidade de intervenção. & $\begin{array}{l}\text { O produtor foi orientado a isolar a área do entorno para } \\
\text { impedir a aproximação do gado ao local. Assim, foi sugerido } \\
\text { a abertura de uma nova entrada, próxima, para o acesso dos } \\
\text { animais a água. }\end{array}$ \\
\hline 09 & $\begin{array}{l}\text { Localizada em uma capoeira próxima as } \\
\text { culturas de fumo, feijão e milho. O local } \\
\text { estava desprotegido do acesso de pequenos } \\
\text { animais e de possíveis enxurradas. }\end{array}$ & Necessidade de intervenção. & $\begin{array}{l}\text { Necessidade de adoção de práticas conservacionistas como } \\
\text { adubação verde (cobertura do solo) na entressafra, } \\
\text { manutenção da barreira de contenção, troca de cultura nas } \\
\text { proximidades da nascente, para evitar uma possível } \\
\text { contaminação da água e necessidade de manutenção de } \\
\text { vegetação em todo o entorno da nascente. }\end{array}$ \\
\hline 10 & $\begin{array}{l}\text { Estava localizada em meio a uma lavoura de } \\
\text { cana-de-açúcar e no entorno uma pequena } \\
\text { vegetação arbórea isolando-a do canavial. }\end{array}$ & Necessidade de intervenção. & $\begin{array}{l}\text { Ampliar a área de isolamento devido à substituição da } \\
\text { lavoura de cana-de-açúcar por área de potreiro com a } \\
\text { presença constante de animai. }\end{array}$ \\
\hline 11 & $\begin{array}{l}\text { Localizada em meio à vegetação baixa, com a } \\
\text { presença de poucas árvores de pequeno } \\
\text { porte. O ponto de captação estava } \\
\text { completamente aberto, sem nenhuma } \\
\text { proteção. }\end{array}$ & $\begin{array}{l}\text { Nascente preservada, entorno } \\
\text { com mata bem formada e } \\
\text { isolada para não permitir o } \\
\text { acesso de pessoas ou animais. } \\
\text { Distante de lavouras e estradas. }\end{array}$ & $\begin{array}{l}\text { Dado o pleno funcionamento e o bom estado de conservação } \\
\text { da nascente, apenas foi solicitado aos responsáveis que } \\
\text { continuassem com as práticas realizadas. }\end{array}$ \\
\hline 12 & $\begin{array}{l}\text { A nascente se encontrava em meio à } \\
\text { vegetação de porte médio, sem o acesso de } \\
\text { animais, porém com pouca proteção, } \\
\text { acarretando em entupimento por restos de } \\
\text { vegetação. }\end{array}$ & $\begin{array}{l}\text { Nascente preservada. Aumento } \\
\text { da área com vegetação arbórea } \\
\text { e maior isolamento devido à } \\
\text { inativação da trilha que dava } \\
\text { acesso a nascente. }\end{array}$ & $\begin{array}{l}\text { Dado o pleno funcionamento e o bom estado de conservação } \\
\text { da nascente, apenas foi solicitado aos responsáveis que } \\
\text { continuassem com as práticas realizadas. }\end{array}$ \\
\hline
\end{tabular}




\subsection{Atividades de Educação Ambiental}

As atividades de educação ambiental possibilitam dar continuidade ao trabalho de sensibilização e conscientização sobre a importância da preservação ambiental, destacando-se especialmente o papel das florestas, que atuam como um filtro natural, retendo impurezas e melhorando a qualidade da água subterrânea.

Para tal, foram realizadas com as crianças, anualmente, duas trilhas ecológicas. As trilhas ecológicas são um dos meios possíveis de promover a conscientização ambiental. Isso pode ser comprovado por Rorato et al. (2014), realizando atividades de educação ambiental, utilizando trilhas ecológicas como uma das ferramentas para conscientização de crianças, no município de São João do Polêsine, RS. Esses autores evidenciaram que é possível obter um acréscimo no conhecimento adquirido pelos alunos em relação à temática ambiental quando são realizadas atividades práticas, associadas aos problemas ambientais do meio em que os educandos estão inseridos. Ainda conforme esses autores, essas atividades contribuem na formação de cidadãos conscientes, responsáveis e participativos na busca de soluções para resolver ou minimizar os problemas ambientais.

Além desses, também na região da Quarta Colônia de Imigração Italiana, Marcuzzo et al. (2015), utilizando uma trilha interpretativa existente no Parque Estadual Quarta Colônia para sensibilizar os visitantes sobre a importância da preservação das matas ciliares, concluíram que essas representam uma oportunidade para o desenvolvimento humano, tornando-se uma ferramenta eficiente para a promoção da educação ambiental. Assim, pode-se inferir que as atividades de educação ambiental realizadas nesse estudo com crianças em idade escolar, embora não mensuradas em termos quantitativos, contribuem na sensibilização ambiental desses indivíduos.

Durante a realização da trilha, localizada na comunidade de Trombudo, interior de Dona Francisca, RS, as crianças foram convidadas a observar e refletir sobre diversos aspectos do ambiente. Nesse momento, foram enfatizados aspectos como o microclima proporcionado pela presença do componente arbóreo, fazendo-se comparações com a sensação de estar a pleno sol ou em local sombreado e protegido pelas árvores, a diferença existente entre locais preservados e não preservados, a importância da preservação do ambiente para a qualidade da água, aspectos voltados para a erosão do solo, entre outros.

Além disso, abordou-se a grande diversidade de espécies presentes, tanto de flora como de fauna, apresentando algumas espécies encontradas no local e destacando seu papel naquele ambiente. Ao falar sobre as diferentes espécies vegetais que compõe aquele ecossistema, são apresentadas as diversas formas de dispersão dos propágulos das espécies florestais, como sementes dispersas pelo vento (anemocórica), animais (zoocórica) e gravidade (baricórica).

Ressalta-se também a grande importância das matas ciliares, bem como das florestas para as nascentes, na retenção da água das chuvas, bem como o papel do componente arbóreo, diminuindo o impacto da gota da chuva no solo, o que possibilita a infiltração e abastecimento gradual do lençol freático.

Nesse momento, para facilitar a compreensão dos educandos fez-se uso de analogias do papel da mata ciliar para o curso d'água com o papel dos cílios para o olho humano, visto que segundo Bahia (2007), a mata ciliar, como o próprio nome indica, serve de proteção para rios e córregos, assim como os cílios protegem os olhos, podendo por esse motivo ser considerada como de fundamental importância para preservação da natureza.

Além da analogia da mata ciliar com os cílios, busca-se relacionar o papel das árvores e da serapilheira formada pelas mesmas a um guarda-chuva, que protege o solo e amortece o impacto das gotas de água, permitindo que a água infiltre de forma gradual pelo solo, abastecendo o lençol freático e impedindo ou reduzindo a lixiviação de nutrientes e a erosão de sedimentos do solo, reduzindo consequentemente o assoreamento dos cursos d'água.

O uso de analogias no ensino, quando realizadas de forma apropriada, pode ser considerada uma estratégia significativa, que possibilita mediações simbólicas e aprendizagens significativas, 
instigando a participação dos alunos na compreensão dos conceitos apresentados (MONTEIRO, 2005; PEDROSO; AMORIM, 2009). Nesse sentido, a realização da trilha ecológica juntamente com todos os momentos de reflexão e aprendizagem oportunizados por ela, representam uma oportunidade para sensibilizar os educandos sobre a importância de conhecer e cuidar do meio ambiente, contribuindo assim com a formação de adultos conscientes e capazes de tornar estas áreas preservadas e sustentáveis.

Além das trilhas ecológicas, também foram realizados plantios de espécies florestais nativas ao longo do Rio Jacuí e alguns afluentes como o arroio Trombudo. As crianças e responsáveis foram convidados a fazer o plantio de mudas de espécies como louro-pardo, angico-vermelho, araçá, cerejeira, ingá, aroeira pimenteira, guajuvira, entre outras, em Área de Preservação Permanente como uma primeira iniciativa para a recuperação ambiental desses locais.

Esse pensamento pode ser confirmado ao analisar os resultados obtidos por Rorato et al. (2014) desenvolvendo diversas atividades de educação ambiental com alunos do $4^{\circ}$ e $5^{\circ}$ ano da Escola Municipal de Ensino Fundamental La Salle, município de São João do Polêsine, RS. Esses autores, dividindo o estudo em nove encontros, também realizaram, no oitavo encontro, o plantio de espécies florestais nativas em uma propriedade particular às margens do Rio Soturno. Ao analisar os resultados, os autores evidenciaram que ao serem abordados sobre a importância da mata ciliar para preservação dos rios, arroios, sangas e lagos, os alunos aumentaram sua percepção sobre o papel dessa vegetação de 70 para $90 \%$ após o término do projeto. A melhora no resultado foi atribuída às inúmeras atividades realizadas, entre elas o plantio de espécies florestais na mata ciliar. Desse modo, infere-se que a realização de diferentes atividades práticas de educação ambiental, interligadas com os conteúdos teóricos, de forma a complementá-los, são formas eficientes de contribuir para a formação da consciência ambiental.

\section{Conclusão}

Desde a implantação do Programa Proteção de Nascentes (Fonte-Drenada), no ano de 1990, foram realizadas 79 proteções. Das nascentes avaliadas nesse estudo, 50\% foram consideradas preservadas, sendo as práticas recomendadas mantidas pelos proprietários e responsáveis. Nessas nascentes, evidenciou-se que a conscientização da necessidade de mudança do entorno foi absorvida pelos beneficiados, os quais passaram a ter maior responsabilidade e cuidado, evitando práticas que pudessem contaminar o meio ambiente, em especial os córregos d'água ou nascentes. As demais necessitam de algum tipo de intervenção, como a ampliação da faixa abandonada no entorno da nascente e o isolamento da área, adoção de práticas conservacionistas, entre outras.

A realização concomitante de ações práticas como a proteção das nascentes e o trabalho de educação ambiental deve ser realizado de forma continua. Além disso, é fundamental agregar novos participantes, como a adesão de escolas. As crianças, indivíduos que se encontram ainda em formação, quando confrontadas com a realidade ambiental, são capazes de apresentar uma mudança comportamental significativa na maneira de pensar e agir, refletindo na formação de adultos mais conscientes e responsáveis com o meio ambiente.

\section{Referências bibliográficas}

BAHIA. Secretaria de Meio Ambiente e Recursos Hídricos - Semarh. Recomposição Florestal de Matas Ciliares. Salvador: Gráfica Print Folhes, 3.ed.rev. e ampl. 2007. 46p.

BARICHELLO, D. E. Modelo de proteção de vertente para o aprimoramento da qualidade da água no meio rural. [Trabalho de Conclusão de Curso]. Santa Maria: Universidade Federal de Santa Maria, Santa Maria; 2011. 50p. 
BARICHELLO, D. E. Ações práticas e de educação ambiental visando a proteção de nascentes no município de Dona Francisca, RS. [Monografia]. Santa Maria: Universidade Federal de Santa Maria, Santa Maria; 2014. 58p.

BRASIL. Lei no 12651, de 25 de maio de 2012. Institui o novo Código Florestal. Diário Oficial da União, Brasília, DF, 25 maio. 2012. Disponível em:< http://www.planalto.gov.br/ccivil_03/_Ato20112014/2012/Lei/L12651.htm\#art83>. Acesso em 10 de outubro 2014.

CASALI, C. A. Qualidade da água para consumo humano ofertada em escolas e comunidades rurais da região central do Rio Grande do Sul. [Dissertação]. Santa Maria: Universidade Federal de Santa Maria, Santa Maria; 2008. 173p.

CONBOY, M. J.; GOSS, M. J. Natural protection of groundwater against bacteria of fecal origin. J. Contam. Hydrol. 2000;v. 43: p. 1-24.

GANDOLFI, S.; RODRIGUES, R. R. Recomposição de florestas nativas: algumas perspectivas metodológicas para o Estado de São Paulo. Anais... $3^{\circ}$ Curso de Atualização - Recuperação de Áreas Degradadas. Curitiba, PR. FUPEF/UFPR, 1996. v.1. p.83-100.

GONÇALVES, C. S. Qualidade de águas superficiais na microbacia hidrográfica do arroio Lino Nova Boêmia - Agudo - RS. [Dissertação]. Santa Maria: Universidade Federal de Santa Maria, Santa Maria; 2003. 90p.

INSTITUTO BRASILEIRO DE GEOGRAFIA E ESTATÍSTICA - IBGE. Resultados Preliminares do Universo do Censo Demográfico 2010. Disponível em <http://www.ibge.gov.br. Acesso em: Outubro 2014.

MARCUZZO, S. B.; SILVEIRA, V.; LOPES, E.; MINUZZI, T. Trilhas interpretativas, uma ferramenta eficiente para educação ambiental. Educação Ambiental em Ação, v. 13, p. 1-9, 2015.

MIRANDA, M. C. P. C.; MUNIZ, F. H. Impacto do gado bovino sobre os ecossistemas do Parque Estadual do Mirador - PEM. Pesquisa em Foco, v. 17, n.1, p. 31-42, 2009.

MONTEIRO, A. M. Entre o estranho e o familiar: o uso de analogias no ensino de história. Cad. Cedes, Campinas, vol. 25, n. 67, p. 333-347, set./dez. 2005.

NAVE, A. G. Banco de sementes autóctone e alóctone, resgate de plantas e plantio de vegetação nativa na Fazenda Intermontes, município de Ribeirão Grande, SP. 2005. 218f. Tese (Doutorado em Recursos Florestais) - Escola Superior de Agricultura Luiz de Queiroz, Piracicaba, 2005. 
PEDROSO, C. V.; AMORIM, M. A. L. Uso de uma atividade didática baseada em analogia para o ensino de genética: o que há de comum entre dois prédios iguais e cromossomos homólogos? Anais... X Salão de Iniciação Científica, PUCRS, 2009.

PINZON, S. A.; BARICHELLO, D. E. Comunicação pessoal. 2014.

REIS, A., KAGEYAMA, P.Y. Restauração de áreas degradadas utilizando interações interespecíficas. In: KAGEYAMA, P.Y.; OLIVEIRA, R.E.; MORAES, L.F.D.; ENGEL, V.L.; GANDARA, F.B. (Eds.) Restauração Ecológica de Ecossistemas Naturais. Botucatu: Fundação de Estudos e Pesquisas Agrícolas e Florestais (FEPAF), 2003. p. 91-100.

RORATO, G. G.; CANTO-DOROW, T. S.; RORATO, D. G.; ROSITO, J. M. Educação Ambiental e o despertar para a cidadania. Reget. 2014;v. 18 (n. 2): p. 745-752.

SCHNEIDER, P. R., GALVÃO, F., LONGHI, S. L. Influência do pisoteio de bovinos em áreas florestais. Floresta, Curitiba, v. 9, n. 1, p. 19-23. 1978. 